\title{
Bilateral internal carotid artery and vertebral artery dissections with retinal artery occlusion after a roller coaster ride - case report and a review
}

\author{
Lunapark trenine binmeye bağlı iki taraflı internal karotid ve \\ vertebral arter diseksiyonu ile beraber retinal arter oklüzyonu: \\ Olgu sunumu ve literatür incelemesi
}

\author{
Yonca ÖZKAN ARAT, ${ }^{1}$ John VOLPI, ${ }^{2}$ Anil ARAT, ${ }^{3}$ Richard KLUCZNIK, ${ }^{4}$ Orlando DIAZ ${ }^{4}$
}

\begin{abstract}
We present the first case of a woman with no significant medical history who developed dissections of bilateral carotid and bilateral vertebral arteries, as well as a retinal artery occlusion, after a roller coaster ride. A 35-year-old woman developed right-sided neck pain followed by a frontal headache immediately after a roller coaster ride. Five days after the incident, she developed complete loss of vision in her right eye for two hours. Subsequently, the vision improved but remained significantly decreased. On presentation, her visual acuity was 20/200 in the right and 20/20 in the left eye. Her fundus exam revealed retinal edema in the superotemporal retinal artery distribution without any visible emboli. Her neurological exam was otherwise normal. The cerebral angiogram showed bilateral internal carotid and vertebral artery dissections. The patient remained stable with conservative therapy without further worsening of vision or any new neurological deficits. Outcomes for cervicocephalic arterial dissection are usually favorable, but early diagnosis is critical for initiation of appropriate treatment of possible complications. Physicians must have a high index of suspicion for arterial dissection when patients note any headache, neck pain or vertigo triggered by violent motion after leisure activities such as roller coaster rides.
\end{abstract}

Key Words: Carotid artery; dissection; retinal artery; vertebral artery.
Bu yazıda, lunapark trenine (roller coaster) binmesini takiben iki taraflı internal karotid ve iki taraflı vertebral arter diseksiyonu ile beraber retinal arter oklüzyonu gelişen, bilgilerimize göre, literatürdeki ilk olguyu sunuyoruz. Otuz beş yaşında sağlıklı bir kadın hastada, lunapark trenine binmesini takiben, sağ taraflı boyun ağrısı ve frontal başağrıs1 gelişmiştir. Bundan beş gün sonra hastanın sağ gözünde 2 saat süren tam görme kaybını takiben, bu gözde görme düzelmiş fakat normale göre çok düşük düzeyde kalmıştır. Hastanın ilk muayenesinde sağ gözde görmesi 20/200 ve sol gözde 20/20 düzeyinde bulunmuştur. Fundus muayenesinde üst temporal arter boyunca ödem izlenmiş, emboli görülmemiş̦tir. Hastanın bunun dışında nörolojik muayenesi normaldi. Yapilan beyin anjiyografisinde, iki tarafl 1 internal karotid ve iki taraflı vertebral arter diseksiyonu görülmüştür. Hasta, konservatif tedavi ile stabil olarak kalmış ve görmesinde daha fazla düşme veya yeni nörolojik kayıp izlenmemiştir. Baş-boyun arter diseksiyonlarında prognoz çogunlukla iyidir, fakat olası komplikasyonların önlenmesi için erken teşhis çok önelidir. Lunapark treni gibi ani ve hızlı hareketlere maruz kalınmasını takiben başağrısı, boyun ağrısı, baş dönmesi gibi şikayetler gelişen hastalarda arteriyel diseksiyon için yüksek şüphe bulunmalıdır.

Anahtar Sözcükler: Karotid arter; diseksiyon; retinal arter; vertebral arter.

\section{CASE REPORT}

A 35-year-old woman with no significant medical history developed right-sided neck pain followed by a frontal headache immediately after a roller coaster ride, which was not relieved with acetaminophen/ propoxyphene (Darvocet- $\left.\mathrm{N}^{\circledR} 100\right)$. Five days after the incident, she developed complete loss of vision in her right eye for two hours. Subsequently, the vision

\footnotetext{
${ }^{1}$ Department of Ophthalmology, University of Wisconsin, Madison, WI;

${ }^{2}$ Department of Neurology, The Methodist Hospital, Houston, TX; ${ }^{3}$ Department of Radiology, University of Wisconsin, Madison, Wisconsin; ${ }^{4}$ Department of Radiology, The Methodist Hospital, Houston, TX, USA.
} 
improved but remained significantly decreased compared to baseline. She was admitted to our hospital for evaluation and treatment. On presentation, her visual acuity was 20/200 in the right eye and 20/20 in the left eye. She had an afferent pupillary defect on the right. Her fundus exam revealed retinal edema in the superotemporal retinal artery distribution without any visible emboli. Her neurological exam was otherwise normal without any other neurological deficit. The patient underwent a cerebral angiogram, which demonstrated occlusion of the right internal carotid artery (Fig. 1a) and dissections involving the left internal carotid and both vertebral arteries (Fig. 1b-d). The left internal carotid artery injection showed preferential opacification of all intracranial arteries from the left internal carotid artery (Fig. 2). There was complete occlusion of the right internal carotid artery with retrograde perfusion of the right ophthalmic artery. Conservative management was offered to the patient based on the angiogram, and she was started on anticoagulation with 12 units/kg-hr intravenous heparin infusion for four days followed by oral Coumadin for three months. The patient then remained stable without further worsening of vision or development of any new neurological deficits.

\section{DISCUSSION}

Among all patients admitted to the hospital for blunt trauma, the incidence of carotid artery injury is approximately $0.1 \%,{ }^{[1]}$ and that of vertebral artery injury approximately $0.5 \% .^{[2]}$ Four-vessel cervical dissections are extremely rare, and there have been about seven cases reported in the literature. ${ }^{[3-9]}$ Furthermore, our case also had retinal artery occlusion associated with ipsilateral ophthalmic artery occlusion secondary to internal carotid artery dissection. There have been only a few reports of central/ branch retinal artery occlusion associated with cervical dissections. ${ }^{[10-18]}$ To our knowledge, we are reporting the first case of a woman with no history of collagen vascular disease who developed dissections of both carotid and both vertebral arteries, as well as a retinal artery occlusion, after a roller coaster ride.

Arterial dissection is the most common etiology for stroke in a young per- son. ${ }^{[19]}$ Trauma and connective tissue disorders represent the major risk factors. ${ }^{[20]}$ Most cervical dissections are atraumatic or associated with only mild trauma. ${ }^{[3]}$ Traumas due to roller coaster rides have been rarely associated with cervical arterial dissections. There have been five cases of vertebral artery dissection and seven cases of internal carotid artery dissection
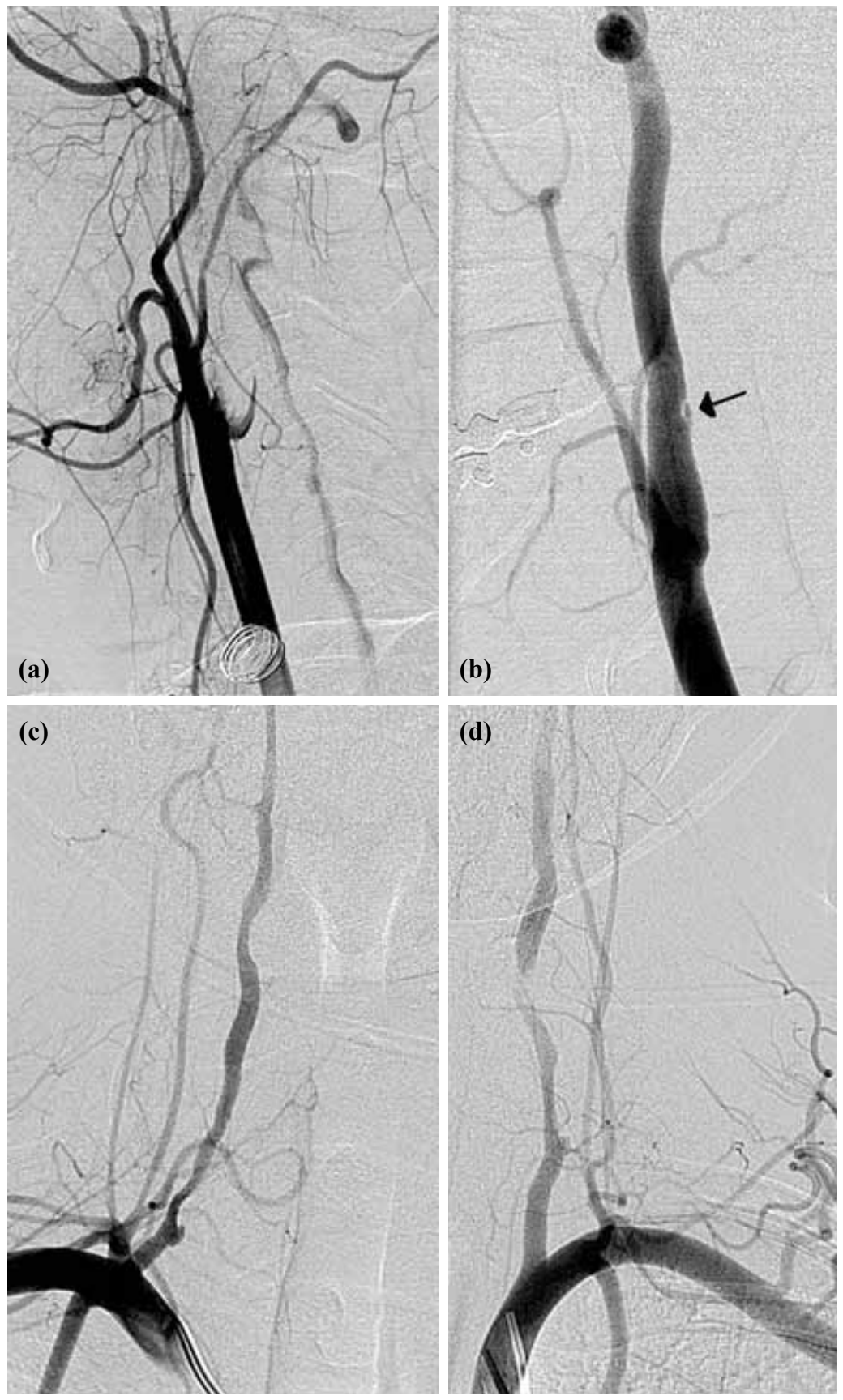

Fig. 1. (a) Right common carotid arteriogram showing total occlusion of the internal carotid artery at its origin. (b) Left common carotid arteriogram demonstrates a small dissection flap (arrow) on the posterior wall of the internal carotid artery. (c) Right subclavian arteriogram shows dissection flap and a small pseudoaneurysm at approximately the C7-T1 level; distal cervical vertebral artery is involved to a lesser extent. (d) Left subclavian artery shows a similar involvement of the vertebral artery on the right side. 


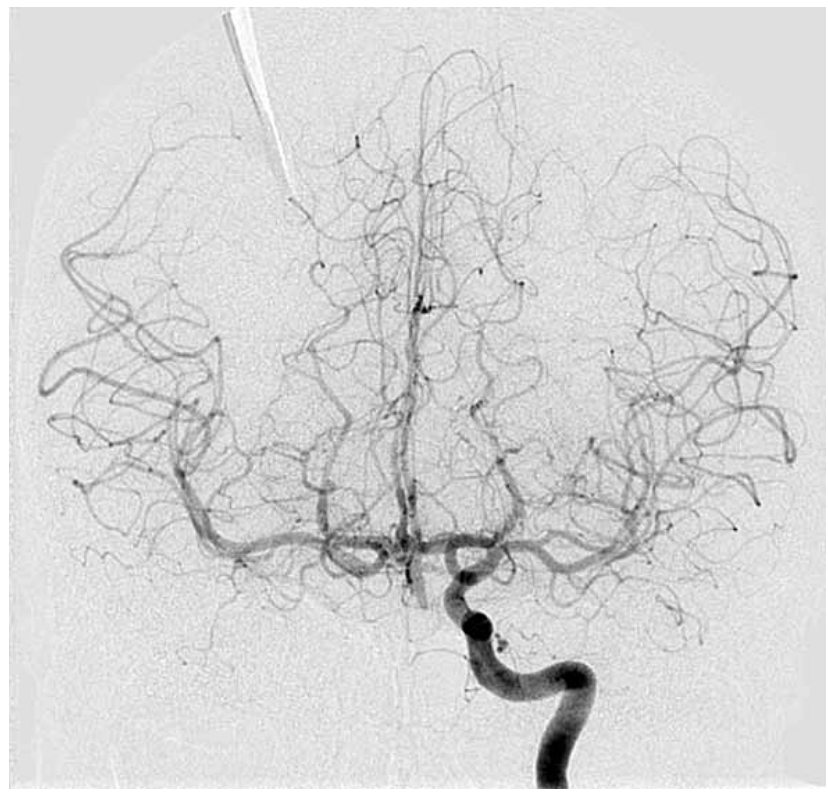

Fig. 2. Left internal carotid arteriogram shows preferential opacification of the contralateral carotid circulation through the anterior communicating artery. The vertebrobasilar circulation distal to the midbasilar segment also opacifies in this injection via the posterior communicating arteries bilaterally.

reported after roller coaster rides. ${ }^{[1-26]}$ None of these cases had involvement of both bilateral vertebral and carotid arteries. The complex and abrupt changes in motion have the potential to cause sudden hyperextension, hyperflexion or rotation of the neck, which may cause injury to the carotid or vertebral arteries and create intimal tears. ${ }^{[1,24]}$ These rides can generate force in excess of 4 gravitational forces (Gs), which in combination with neck movements could potentially rip the carotid intima. ${ }^{[22]}$ Subintimal penetration of blood with subsequent longitudinal extension of intraluminal hematoma may cause vessel narrowing that may progress to complete obstruction, aneurysm formation, or both ${ }^{[24]}$ Certain people, such as those with underlying connective tissue disorders, may be more susceptible to arterial dissection. However, there is evidence to suggest that patients who are phenotypically normal may have ultrastructural abnormalities of connective tissue. ${ }^{[27]}$ In our patient, the work-up for an underlying connective tissue disease was negative.

It should be noted that recognition of cervicocephalic arterial dissections is often delayed since the presenting symptoms, including headache, vertigo and neck pain, are non-specific, and the diagnosis may not be considered until there is evidence of neurological impairment. A high index of suspicion is therefore necessary for the diagnosis in the presence of nonspecific symptoms that usually precede the neurological deficits for up to three weeks or more. ${ }^{[23,24]}$ If the diagnosis is suspected, targeted investigations such as axial T1- weighted magnetic resonance imaging (MRI) with fat saturation can be used to image the neck vessels. MRI has been shown to be a sensitive, noninvasive modality for diagnosis. ${ }^{[28]}$ However, conventional cerebral angiography remains the gold standard ${ }^{[29]}$ In general, the outcomes for cervicocephalic arterial dissections are usually favorable with either anticoagulant or antiplatelet therapy, but early diagnosis is crucial for initiation of appropriate treatment and monitoring of potential complications. ${ }^{[21]}$

Internal carotid artery dissections may be associated with ocular complications such as ophthalmoplegia, Horner syndrome, ischemic optic neuropathy, and arterial vessel occlusions. ${ }^{[11]}$ Central retinal artery occlusions caused by carotid artery dissections are exceedingly rare compared with the other ophthalmologic signs in these patients. Most authors believe it results from ocular hypoperfusion rather than an embolic process because of the existence of reversal of the ophthalmic flow. ${ }^{[11,14]}$ There have been only a few reports of branch retinal artery or cilioretinal artery occlusion associated with a visible emboli. ${ }^{[13,17]}$ Our patient had retinal edema in the superotemporal retinal artery distribution without any visible emboli. We believe that she either had reperfused central retinal artery occlusion with retrograde flow with evidence of increased retinal insult superotemporally or branch retinal artery occlusion. The recognition of an internal carotid artery dissection is of utmost importance because a risk of hemispheric stroke exists in one-third of the patients, usually within the first week. ${ }^{[11]}$ Early diagnosis and treatment of internal carotid artery dissection are important to reduce the risk of hemispheric stroke. All patients with central retinal artery occlusion should be questioned about associated pain or other extraocular symptoms, such as tinnitus, preceding the occurrence of central retinal artery occlusion. ${ }^{[14]}$

In conclusion, outcomes in cervicocephalic arterial dissection are usually favorable with anticoagulant therapy, but early diagnosis is critical for initiation of appropriate treatment of possible complications. Physicians must have a high index of suspicion for arterial dissection when patients note any headache, neck pain, vertigo, or tinnitus triggered by violent motion after leisure activities such as roller coaster rides.

\section{REFERENCES}

1. Biffl WL, Moore EE, Ryu RK, Offner PJ, Novak Z, Coldwell $\mathrm{DM}$, et al. The unrecognized epidemic of blunt carotid arterial injuries: early diagnosis improves neurologic outcome. Ann Surg 1998;228:462-70.

2. Biffl WL, Moore EE, Elliott JP, Ray C, Offner PJ, Franciose RJ, et al. The devastating potential of blunt vertebral arterial injuries. Ann Surg 2000;231:672-81.

3. Chakrapani AL, Zink W, Zimmerman R, Riina H, Benitez R. Bilateral carotid and bilateral vertebral artery dissection following facial massage. Angiology 2008;59:761-4. 
4. Marshman LA, Ball L, Jadun CK. Spontaneous bilateral carotid and vertebral artery dissections associated with multiple disparate intracranial aneurysms, subarachnoid hemorrhage and spontaneous resolution. Case report and literature review. Clin Neurol Neurosurg 2007;109:816-20.

5. Yong RL, Heran NS. Traumatic carotid cavernous fistula with bilateral carotid artery and vertebral artery dissections. Acta Neurochir (Wien) 2005;147:1109-13.

6. Nadgir RN, Loevner LA, Ahmed T, Moonis G, Chalela J, Slawek K, et al. Simultaneous bilateral internal carotid and vertebral artery dissection following chiropractic manipulation: case report and review of the literature. Neuroradiology 2003;45:311-4.

7. Coric D, Wilson JA, Regan JD, Bell DA. Primary stenting of the extracranial internal carotid artery in a patient with multiple cervical dissections: technical case report. Neurosurgery 1998;43:956-9.

8. Rees JH, Valentine AR, Llewelyn JG. Spontaneous bilateral carotid and vertebral artery dissection presenting as a ColletSicard syndrome. Br J Radiol 1997;70:856-8.

9. Grau AJ, Brandt T, Forsting M, Winter R, Hacke W. Infection-associated cervical artery dissection. Three cases. Stroke 1997;28:453-5.

10. Rao TH, Schneider LB, Patel M, Libman RB. Central retinal artery occlusion from carotid dissection diagnosed by cervical computed tomography. Stroke 1994;25:1271-2.

11. Biousse V, Touboul PJ, D’Anglejan-Chatillon J, Lévy C, Schaison M, Bousser MG. Ophthalmologic manifestations of internal carotid artery dissection. Am J Ophthalmol 1998;126:565-77.

12. Godfrey DG, Biousse V, Newman NJ. Delayed branch retinal artery occlusion following presumed blunt common carotid dissection. Arch Ophthalmol 1998;116:1120-1.

13. McDonough RL, Forteza AM, Flynn HW Jr. Internal carotid artery dissection causing a branch retinal artery occlusion in a young adult. Am J Ophthalmol 1998;125:706-8.

14. Mokhtari F, Massin P, Paques M, Biousse V, Houdart E, Blain $P$, et al. Central retinal artery occlusion associated with head or neck pain revealing spontaneous internal carotid artery dissection. Am J Ophthalmol 2000;129:108-9.

15. Lubin J, Capparella J, Vecchione M. Acute monocular blindness associated with spontaneous common carotid artery dis- section. Ann Emerg Med 2001;38:332-5.

16. Schneider U, Hermann A, Ernemann U, Bartz-Schmidt KU. Central retinal artery occlusion secondary to spontaneous internal carotid artery dissection. Retina 2004;24:979-81.

17. Hwang JF, Chen SN, Chiu SL, Wu SL. Embolic cilioretinal artery occlusion due to carotid artery dissection. Am J Ophthalmol 2004;138:496-8.

18. Akiyama Y, Tanaka M, Hayashi J, Fujimoto M, Harada K, Nakahara I, et al. Internal carotid artery obstruction derived from persistent arterial wall dissection associated with old trivial trauma. Neurol Med Chir (Tokyo) 2006;46:395-7.

19. Leys D, Lucas C, Gobert M, Deklunder G, Pruvo JP. Cervical artery dissections. Eur Neurol 1997;37:3-12.

20. Schievink WI, Mokri B, Whisnant JP. Internal carotid artery dissection in a community. Rochester, Minnesota, 19871992. Stroke 1993;24:1678-80.

21. Schneck M, Simionescu M, Bijari A. Bilateral vertebral artery dissection possibly precipitated in delayed fashion as a result of roller coaster rides. J Stroke Cerebrovasc Dis 2008; 17:39-41.

22. Blacker DJ, Wijdicks EF. A ripping roller coaster ride. Neurology 2003;61:1255.

23. Stahlfeld KR, Roozrokh HC. Traumatic bilateral ECCA injury in a roller coaster enthusiast. Ann Vasc Surg 2002;16:505-8.

24. Lascelles K, Hewes D, Ganesan V. An unexpected consequence of a roller coaster ride. J Neurol Neurosurg Psychiatry 2001;71:704-5.

25. Kettaneh A, Biousse V, Bousser MG. Neurological complications after roller coaster rides: an emerging new risk? Presse Med 2000;29:175-80. [Abstract]

26. Burneo JG, Shatz R, Papamitsakis NI, Mitsias PD. Neuroimages: amusement park stroke. Neurology 2000;55:564.

27. Brandt T, Hausser I, Orberk E, Grau A, Hartschuh W, AntonLamprecht I, et al. Ultrastructural connective tissue abnormalities in patients with spontaneous cervicocerebral artery dissections. Ann Neurol 1998;44:281-5.

28. Ozdoba C, Sturzenegger M, Schroth G. Internal carotid artery dissection: MR imaging features and clinical radiological correlation. Radiology 1996;199:191-8.

29. Ganesan V, Savvy L, Chong WK, Kirkham FJ. Conventional cerebral angiography in children with ischemic stroke. Pediatr Neurol 1999;20:38-42. 